CORE DEBRIS BEHAVIOR AND INTERACTIONS WITH CONCRETE

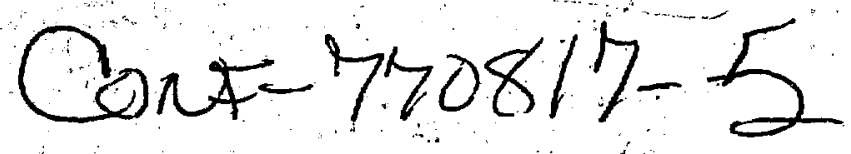

Louis Baker, Jr.

\author{
Prepared for \\ International Seminar on \\ Containment of Fast Breeder Reactors \\ San Francisco, CA \\ August 22-23, 1977
}
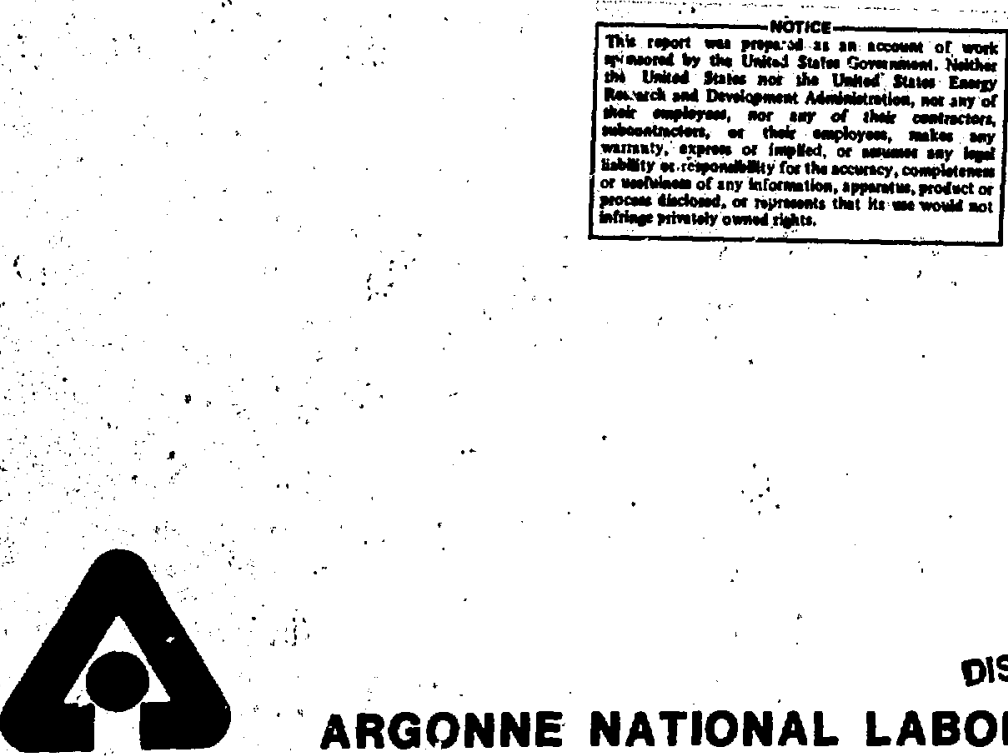

. DISTRIBUTION

ARGONNE NATIONAL LABORATORY, ARGONNE, ILLINOIS

operated under contract W-31-109-Eng-38 for the U. S. ENERGY RESEARCH AND DEVELOPMENT ADMINISTRATION 


\section{CORE DEBEIS BEHAVIOR AND INTERACTIONS WITH CONCRETE}

Iouis Baker, Jr. Reactor Analysis and Safety Division. Angonne National Laboratory

9700 South Cass Avenue

Angonine, Tleinois 60439. USA

\section{IMTRODUCTION :}

Considerations' of the behavior of IMFBR core detris begin just after the fuel has reached a subcritical state following a hypothetical core-disruptive ccident (HCDA). In an early-sized IMFBR such as FFTF or CRBR, the loss-of-flow accident with failure to scram (LOF-HCDA) could bring the core to a largely molten - tate when either a mild nuclear transierit or gradual overptessurization combined with a melting attack on the upper structures is able to overcome their structural resistance, and cause molten core debris to be ejected from the core region. Core debris ejection is expected to be preferentially upward because of the tendency of molten stainless steel cladding to freeze in the lower portions of the core to form blockages early in the accident sequence. Eventually, some fraction of the core debris that remains in the original core region will melt through the lower blockages and downward removal of some of the core debris will occur.

Other hypothetical accidents such as the transient overpower accident with failure to scram and the single subassembly blockage accident could tnrminate with the ejection of only small quantities of core debris from the core region. Accordingly, analyses of core debris following the IOF-HCDA should encompass the behavior expected in other, less severe accident situations.

The initial post-accident consideration concernis the behavior of core debris within the reactor vessel. For small reactors, such as FFTF, it has been shown (I) to be very likely that, the core debris would achieve a coolable configuration within the vessel and the core debris would remain stable as long as some heat removal from the reactor vessel continued. The FFT' reactor is shown in Fig. 1. For larger reactors or for the postylated fallure of long term heat removal systems, reactor vessel failure could occur with conseguent relocation of the core debris into the cavity below the reacto: vessel.

The second important post-accident coneideration is that of core debris

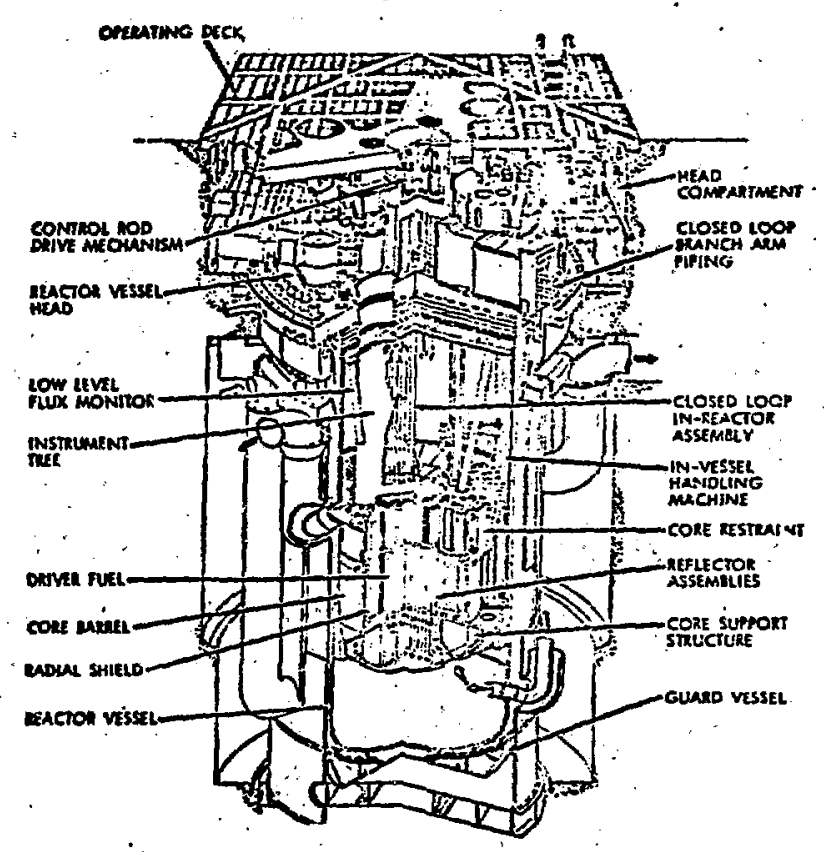

Fig. 1. FFIF Reactor

behavior in the reactor cavity. The design of the cavity, may or may not include special features to cope with the core debris. The current design of the German SNR-300 reactor includes a cooled catcher-tank for the core [2], which is shown in Fig. 2. For the CRBR, a "parallel design" option "included a cooled core-retention.systom in the reactor cavity [3]. A cross-section of the core retention bed is shown in Fig. 3. How ever, in the current design, reliance is placed on an inherent retention concept based on the large quantity of concrete in the cavity floor [4]. The third important consideration is the behavior of the core debris in the concrete below the reactor vessel.

In this paper, the available information on core debris behavior. within the resctor vessel, in the reactor cavity and in.the concrete base nat are. reviewed. A considerable quantity of 


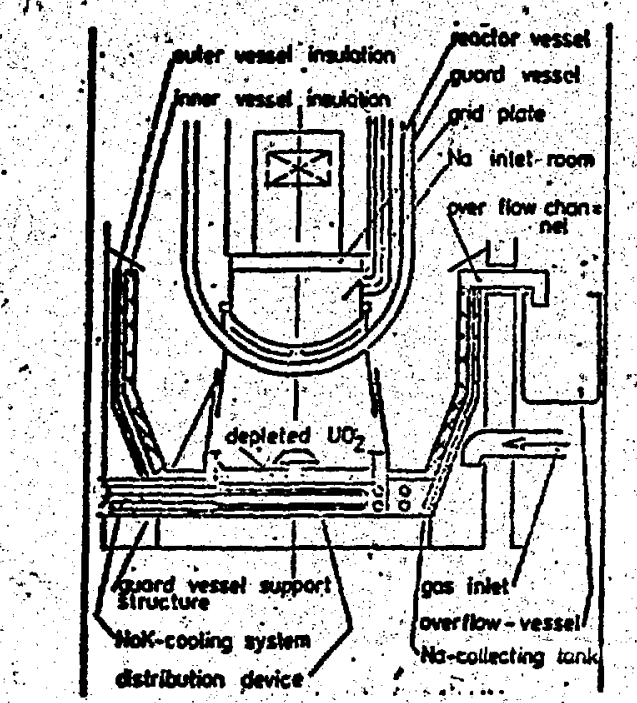

Ifg. 2. Ex-vessel core Cateher concept for the SNR-300 Reactor
Information has been developed over the past few years on which to base analyses of such behavior. Overall response of the reactor containment and the expected behavior of fuel, sodium, and fission products within the containment building are treated in the companion papers in this seminar.

\section{IN-VESSEL CONSIDERATIONS}

Breakthrough of the structures just above the active core region following a LOE-HCDA will result in a vigorous ejection of two-phase fluid (fuel/steel liquid and vapor). "The molten fuel and steel which is ejected. is expected to be quenched in the large sodium plenum above the core.

\section{Core Debris Fragmenitation}

an extensive series of experiments has demonstrated the strong tendency for molten $\mathrm{VO}_{2}$ and molten steel to fragment on quenching in sodium [5]. Experiments have ranged from laboratory tests with ingle droplets to tests with $30 \mathrm{~g}$ batches and finally to tests with several kilograms of molter core debris. The

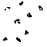

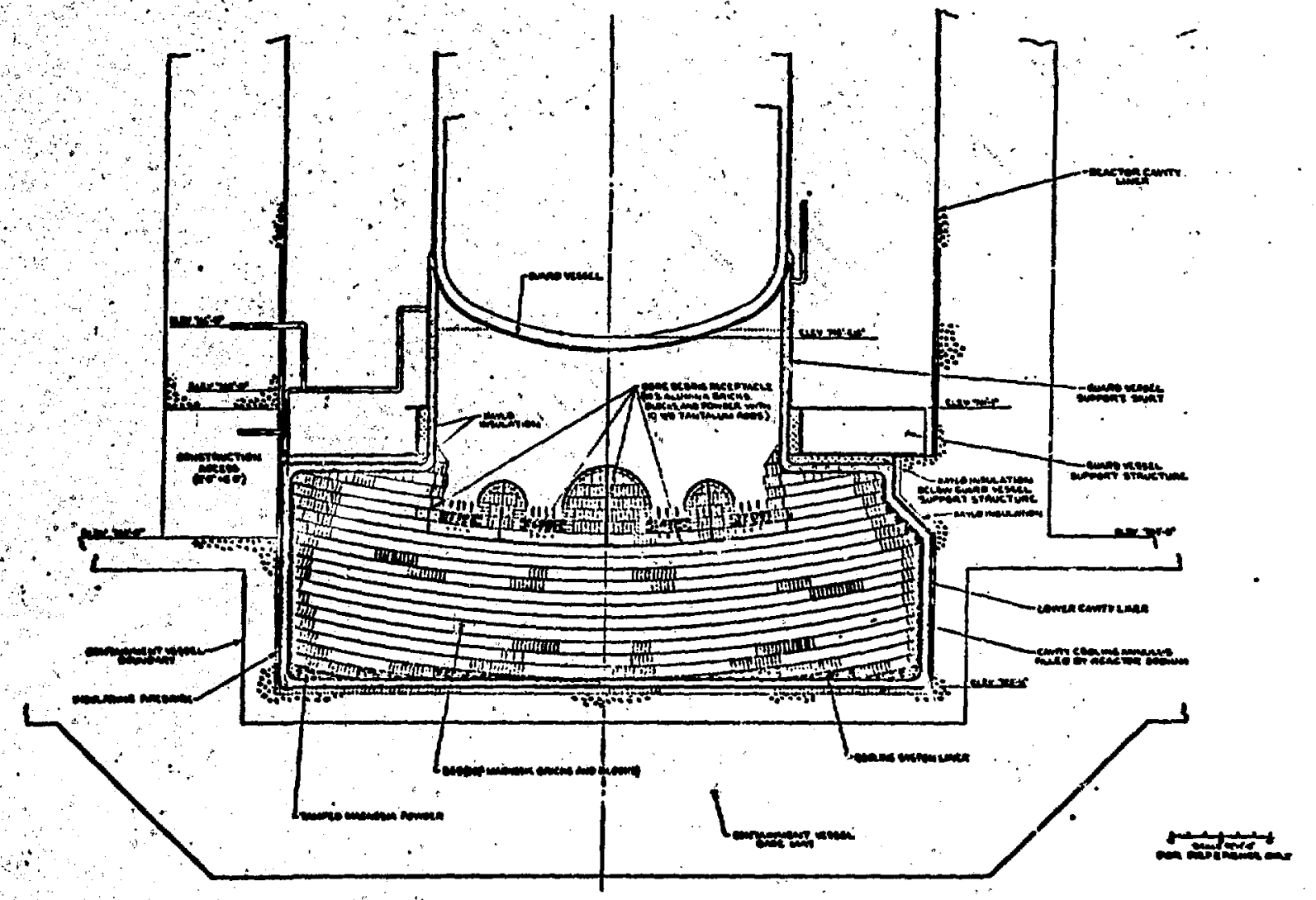

F1g. 3. Ex-venesl Core Catcher Sacrificlal bed Concept for the Parallel Design Option of the Clinch River Breoder Aanctor Plant 
test. have shown that when molten core debris is injected intc. an excess of sodium, the core debris forms particilate with particle size distribution range from 0 to $n 5000$ um with mean diameters firom 50 to $1000 \mu \mathrm{m}$ (see Fig. 4). Particulate fuel and steel have also been generated in many in-pile tests performed as part of the IMFBR safety program and particulate having similar size distributions was obtained as indicated in Fig. 4.

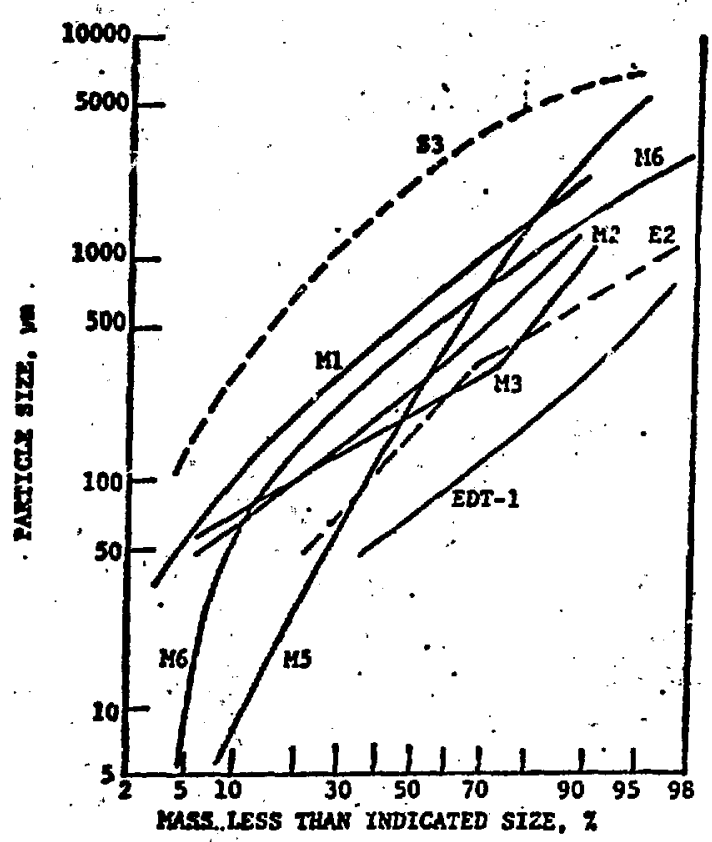

Fig. 4. Particle size Distributions of $\mathrm{vO}_{2}$ from out-of-pile 5xperiments $\mathrm{ki}, \mathrm{M2}, \mathrm{M3}, \mathrm{M}$, M6, and EDT-i, and from In-pile Experiments 53 and $E 2$.

\section{Particulate settling}

The particulate gererated by the ejection and quenching of molten core debris in the sodium plenium is expected to settle downward onto the available horizontal surfaces to form particulate beds. Coolant flow through the plenum would cause some of the particulate to be swept into the primary piping instead of settling downward. An analysis of settling and sweepout was made for the conditions expected in FETF following a JOF-HCDA which showed that more than $85 \%$ of the core debris would be expected to remain wthin the reactor vessel [6]. Material. . escaping the vessel would be composed of Ine particles which would tend to remain suspended in slowly flowing sodium. The rctes of settiing for typical particle alze distributions are such that bed buildup is substantially complete in about $100 \%$

\section{Heat Generation in Particulate Beds}

Thie magnitude of the afterheat generated by the radioactive decay of fission products and activation products depends on the operating history of the reactor. Short-livea activity builds up rapidly so that the heat generation rate relative to operating rate just after nuclear shutdown is almost independent of operating tine after only a few-days of operation. The decay power level at shutdown is 27 of the operating power level and decreases to 238 at $100 \mathrm{~s}$ and to 218 at $25000 \mathrm{~s}$. An analysis of the decay heat source indicated that it was convenient to consider four groups of elements [7]. About 508 of the total heat generation is associated with nonvolatile' oxide-forming elements which should remain dissolved in the fuel. About 20: of the ?ast originates in nonvolatile metallic elements. About 258 originates in volatile elements which are soluble in sodium and 58 is associated with the noble gas fission products. The analysis indicates that the non-volatile elements are likely to remain distributed within the particulate bed so that about 70 s of the total decay heat source. should remain dissolved in the particulate.

\section{Particulate Bed Coolability}

Iong term stability of a particulate bed on a horizontal surface depends primarily on the ability to transfer the internally generated heat upward to overlying sodium. The limiting heat transfer capability corresponds to the initiation of a dryout within the bed. Bed dryout is expected to lead to overheating and a melting attack on the substrate. The important upward heat transfer processes are cunduction and boiling. Conauction heat transfer depends upon having an overlying pool which is maintained in $=$ subcooled condition. Conduction is capable of cooling beds -up to a loading of about $130 \mathrm{~kg}-$ fnel $/ \mathrm{m}^{2}$ at an internal heat generation rate of $40 \mathrm{MW} / \mathrm{m}^{3}$ of fuel ( ${ }^{3} 3$ t average FFTF power) [8]. Actual bed depth for such a case is about $25 \mathrm{~mm}$. Coolable bed loadings are increased by a factor of between 2 and 3 by boiling before inciplent dryout occurs. 'Moreover, heat' transfer by boiling is effective even if the overlying sodium popl is at raturation temperature. Also, boiling has been shown to effect a significant degree of self-leveling of the larticulate. Maximum heat fluxes under boiling conditions were determined by a series of experiments using electrical heating of the sodium phase of particulate $\mathrm{VO}_{2}$ beds in sodium [8]. Conservative dryout limits are thow in Fig. 5. An underatanding of bed 


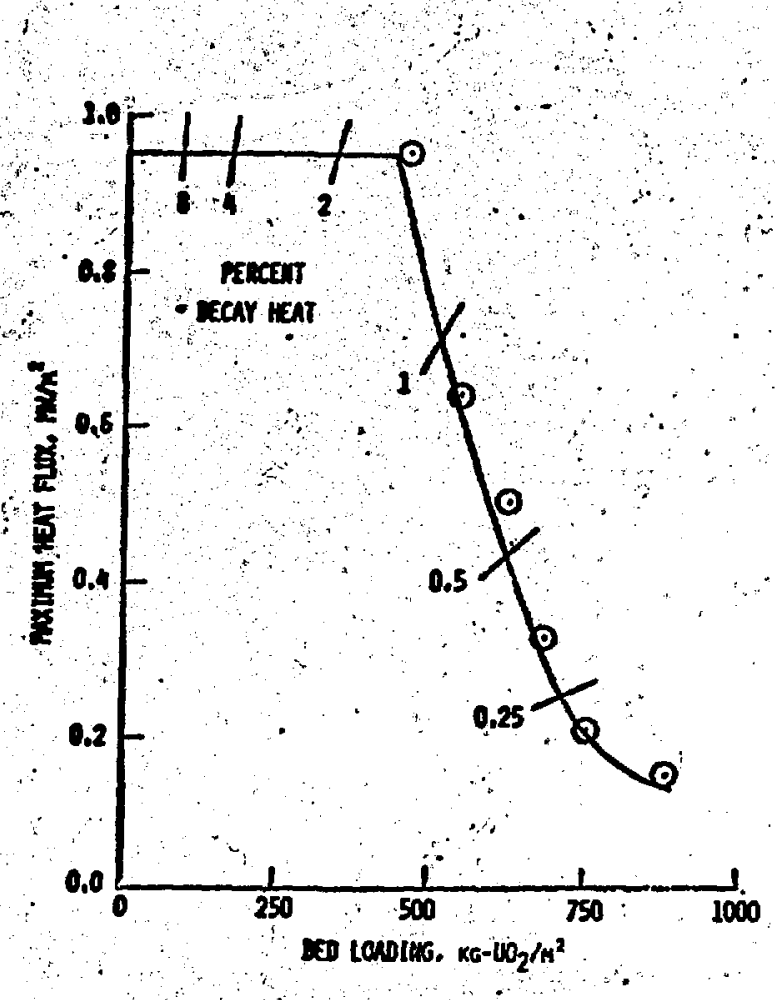

Hg. 5. Coniervative Dryout timits for $\mathrm{UO}_{2}$ Beds in Boiling Sodiua (Experimentàl Data polints for 100-1000 im Size Distribution)

behayior has been augmented by experiments with $v O_{z}$ and metallic particulates in water $[8-10]$ :

In FFTP, there is a baffle surface which is horizontal and covers most of the vessel cross-section above the level of the core [11] (see Fig. 1). The curface area is large enough so that if the entire core-debris inventory, as particulate, were spread uniformily on the bafile, the bed loading would be about $100 \mathrm{~kg}-\mathrm{fuel} / \mathrm{m}^{2}$, which would be coolable by conduction alone $[7]$. The added margin to dryout under boiling conditions Is a good allowance for the uncertainty regarding the initial uniformity of bed depth. The availability of sufricient: bed area was probably the most important factor in the assessment of in-vessel. coolabilitty for FFTF. In CRBR, approxiwitely the same cross-sectional area is available, however, about 2-1/2 times the quantity of core debris and decay heat are fotentially available. For CRBR, in- vestel core-debris retention is possible but would be more difficult to establish With the available data Jase. For larger reactors, the likelihood of permanent invessel core debris retention might be opected to decrease with further increases in the ratio of fuel mass to tross-sectional area. On this basis, the potential for in-vessel coolability is greatly improved for pool-type reactor exptemis.

\section{Behavior of Molten Core Debris}

The quantity of core debris that is not ejected upward from the core region would be expected to moye downward either flowing through or melting through the shlelding structures below the core. In FFTF, there is a spherical surface at the bottom of the core-support structure which would have a significant capability for containment of molten core debris (see Fig. 1). Heat removal would occur by downfacing heat transfer to the sodium in the lower inlet plenum of the reactor. Assessment of capability depends on evaluation of the magnitude of local heat fluxes on the fuel-side of the steel structure and on the ability of natural convection to remove the heat on the sodium side [7].

\section{Conditions in the Lower plenum of the Vesiel}

Because of the large cooling capability at the lower surface of the coresupport structure in FFTE, it was not expected that any significant quantity of core debris would accumulate in. the lower plenum. However, there is adaitional capability for the safe storage of. important quantities of core debris as particulate in the lower curved section of the vessel. It is less than at the upper baffle because of the curvature of lower section. The maximum coolable quantity would correspond to a limiting bed loading at the axial centerline of the yessel bottom. At $u_{1}$ decay heat, this location could accommodate 2358 of the core debris inventory [7]. Eor CRBR, with 2-1/2 times the fuel quantity, about $15 \%$ of the core debris could be coolable on the same basis.

$$
\text { The most likely reason for failure }
$$
of the reactor vessel in an LMFBR of any size would be because of the gradual buildup of a particulate bed to depths exceeding dryout limits.. Details of the dryout process are not completely understood. It is likely that some quantity of teel particulate would be admixed with the fuel particulate. Overheating of the bed would result in steel melting which would then transfer heat very efficiently to the bottom of steel vessel. Recent analyses have indicated that vessel failure would occur as a result of the loss of strength of the steel as it approaches melting and no actual melting of the vessel wall would occur before failure [12]. The nature of the meltthrough process indicates that a large area of the vessel frould be expected to fail at one time so that the core debris, i.e., particulate fuel, molten steel, and overiying sodium, would flow out of vessel quite suddenly.

The total time elapsed from core alsruption to vessel- failure could range 
from 21000 to much longer times (4]. The longer delays could result from repeated processes of fragmentation, bed formation, bed dryout, debris overheating and fail'ure of successive barriers within the internal structures and finally at the vessel bottom.

\section{CORE DEBRIS BEHAVIOR IN THE REACTOR CAVITY}

\section{Core Debris Fragmentatian under Ex-vessel conditions}

The rapid flow of core debris into the reactor cavity would occur alinost simirltaneous with the flow of sodium from the vessell. Two experiments, designated M-5 and $M-6$, were performed to simulate the conditions of entry of molten fuel and steel into a dry cavity, followed within a few tenths of a second by a large sodium flow [13]. In both experiment's, the molten $\mathrm{UO}_{2}$ was generated by a thermitetype chemical reaction and was found to have been completely fragmented because of Interaction with the sodium. It was noted in the previous section that the entering $\mathrm{UO}_{2}$ might be initially in a fragmented state submerged in a pool of molten steel. If this can be established, then there could be little question about the ini'ial extent of fragmentation of fuel within the reactor cavity.

\section{Cavity Liner Response}

Current designis of reactor cavities usually include a steel liner which is designed to prevent contact between the underlying concrete or brick with sodium, especially in the event of a sinall sodium leak. The current HCDA evaluation for CRBR does not claim any credit for the potential ability of the liner to delay ... : massive contact between the core debris-.. sodium mixture and the underlying materiai [i]. The liner would be subjected to severe thermal stresses over the entire base area because of contact with sodrum. In addition, there could be a sevtre local attack caused by a concerted jet of molten core debris during entry. Recent analysis of the process of jet erosion of molter. -teel on solid steel indicates that jet flow sustained for oniy wl s could be sufficient to penetrate a wl0-mm steel liner [14]. However, liner penetration could probably be prevented by a ceramic inner liner which would decrease the thermal stresses and prevent jet penetration.

\section{cooled crucible concept}

One approach to assuring postaccident fuel containment and heat removal is to convert the reactor cavity into a cooled crucible. This was recommended as the beat approach in recent study [15] as shown in Fig. 6. The concept is. simple in principle; however, it suffers Erom the disadvantage that active conling must begin elmost immediately or the cooling surface could be destroyed. Design of the cooling system requires a knowledge of the magnitude of local heat fluxes from the core debris in the downward and sideward directións. Heat must be removed from the sodium pool' above the core debris as well as from the, bottom and sides.

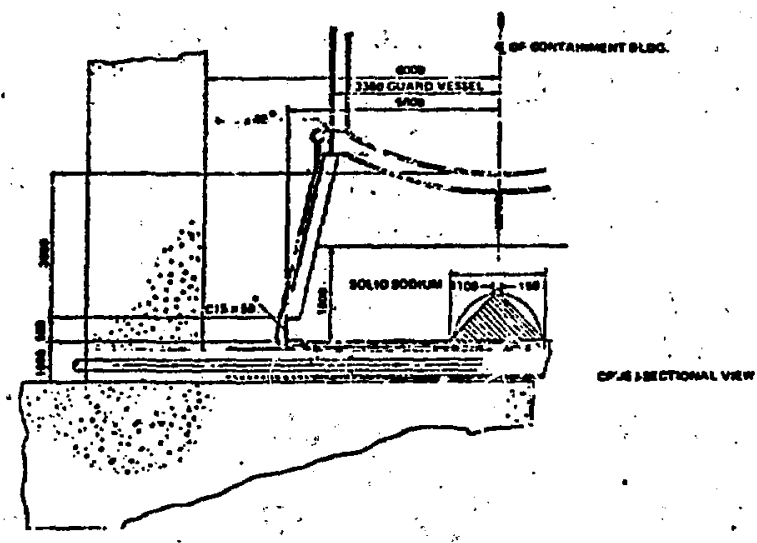

Fig. 6. Cross-section of the cooled Crucible core-retention Concept of Ref. 15:

Heat transfer from fluids with uniforn internal heat sources has been stuclied only recently. Kulacki and Goldstein. [16] were the first to estab"IIsh correlations for the upward and downward hea transfer from horizontal layers having equal boundary tenperatures. The, results were duplicated and extended to greater Rayleigh numbers by Jahn and Reineke [17]. The behavior of idealized horizontal layers has been confirmed by several independent analytical and computer simulation terhniques [17-19]. An approximate model for the. horizontal layer with unequal boundary temperatures has been reported: [20]. Experimental and analytical data for sideward heat transfer from experiments with water have been reported $(21,22]$. These results were. included into an approximate, model for heat transfer in pools having vertical'sidewalls [21]. some data are also available on the local heat fluxes along curved pool boundaries [17].

The available results on beat transfer from pools with uniform internal heat sources, noted above; do provide a reasonable basis for conservative design of cooling systems. Preliminary results are: available from experiments on heat transfer from internaliy heated pools of. molten $\mathrm{UO}_{2}$ [21]. These results have indicated that internal radiation in molten $\mathrm{UO}_{2}$ is a significant mechanism of 
heat transport whlch increased downwara

heat transfer. However these effects can be taken into account in design.

one potential uncertainty is the

effect of boiling of gas evolution on the heat transfer. The threshola for boiling under a particular set of conditions can be predicted using the nonboiling correittions. Heat transfer correlations for bolling conditions have been reported [23]. Boiling agitates the stagnant lower Iayer and increases downward heat transfer relative to sideward. This is shown by the plot of the ratio of sideward to downward heat flux vs boiling rate in Fig. 7 .

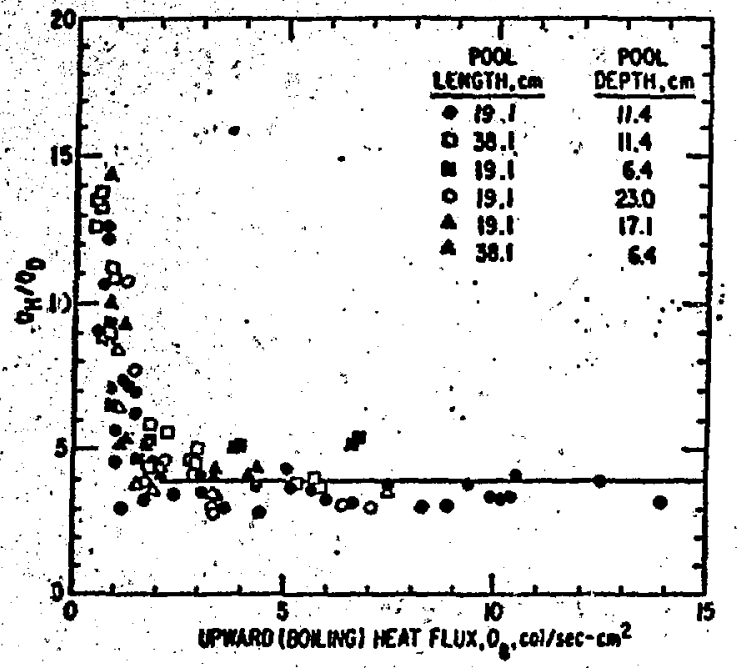

FIg. 7. Experimental Values of the Ratio of sidowara Heat flux, $\mathbf{Q}_{\mathrm{H}}$, to Downward Heat Flux, $Q$, vo the Upward or Boiling Heat Iux, $Q_{B}$, for Internaliy Heated Boliling Nater Pools [23]:

Upward heat transfer occurs by vapor transport in this case. Effects of gas release distributed throughout the volume of the pool, have been shown to hzve effects very similar to those of boiling [24]. There is very iittle data on the effects of gas release from the bounda- . rleat however this would not occur on a continuous basis in a cooled crucible syatem.

Ore other potential uncertainty is the effect on heat transfer of disturbances caused by the continuc us addition of core debris to the pool. Initially, this could be severe, especially for the case where the core debris'entry is by way of' sustained jet concentrating a thermal attack over one small araa. The conconn over fet penetration of the crucible could be alleviated by providing a refractory Ining on the cooling surface: The lining voild be sacrificial in that it would oventually be melted.

\section{Sacrificial Banrien Concept}

The sacriflcial barrier concept is similar to the cooled crucible with a sacrifieial liner except that the liner is guite massive. The melted liner material must be mutually soluble with the fuel so that the heat source is diluted and considerable decay time occurs before the pool approaches. the cooled wall. This assures that the cooling system will have to handle only a uniformly low heat flux. Moreover, the couling system might not be needed for a considerable period of time after the accident.

Most oxide refractory materials are expected to be mutually soluble with mixed oxide fuel in the molten state. However, some refractory materials might be expected to react chemically with sodium. Silica-containing materials, in particular, are expected to react exothermically' with sodium. Also, materials containing water, such as concrete or hydrated minerals, would interact strongly with sodium. A series of cornmercially available firebricks were exposed to sodiun and it was shown the a number of them have adequate compatibility: with sodium, including boiling sodium $[25,26]$. These included bricks which were nearly pure magnesia (MgO) or alumina $\left(\mathrm{Al}_{2} \mathrm{O}_{3}\right)$. silica-containing materials were not satisfactory.

Magnesia, in addition to being resistant to attack by sodium, has a high melting point, a high heat capacity, and a high heat of fusion and was considered to be especially promising as a sacrificial barrier material. Moreover; magnesia and $\mathrm{UO}_{2}$ have been shown to be soluble in the molten state [27]. Accordingly, magnesia was specified as the material for the proposed CRBR parallel design concept [3] (see Fig. 3). Analyses of the rates of penetration of core debris into beds of magnesia brick are complicated by the fact that the magnesia melting at the boundaries is less dense than the fuel puol. Consequentiy, additional convertive effects are introduced at the boundaries because of density gradients. A study of these effects using simulant materials indicated that the downward penetration was greatiy exhanced when the melting material is less dense than the pool [28]. This is shown by the differences in the transient pool shapes and penetration - distances apparent from the experimental - results in Fig. 8. Although there have, been several approximate treatments, there is no accepted correlative or analytical procedure to take account of the perturbing effects of the mass transfer on the overall penetration rate. The mignitude of the effect is apparent in Flg. 9 where calculations of the growth of alten fuel pool into a bed of 


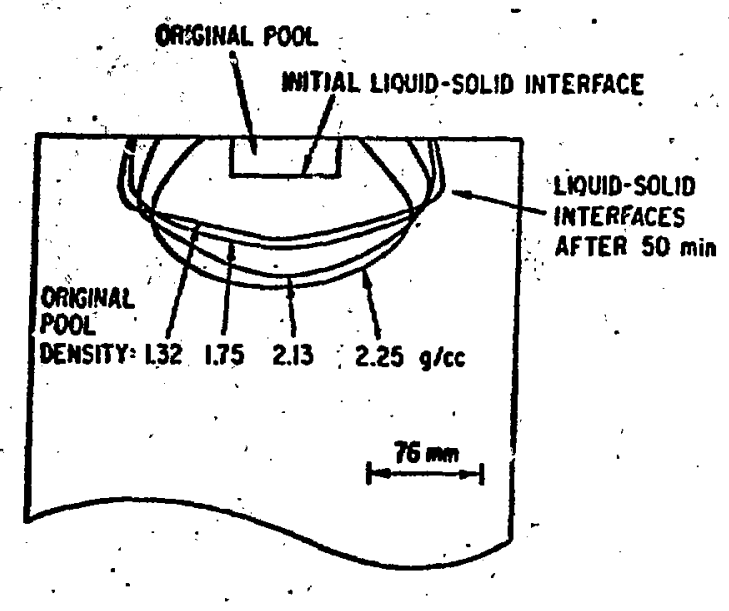

"Fig. 8. Cross sections of Aqueous salt-Solution Pools aftex $50 \mathrm{~min}$ of Internal Heating on a Bed of Hatex Soluble Wax (Density $1.15 \mathrm{~g} / \mathrm{cc}$ ) for Various Values of Initial Pool Density [28].

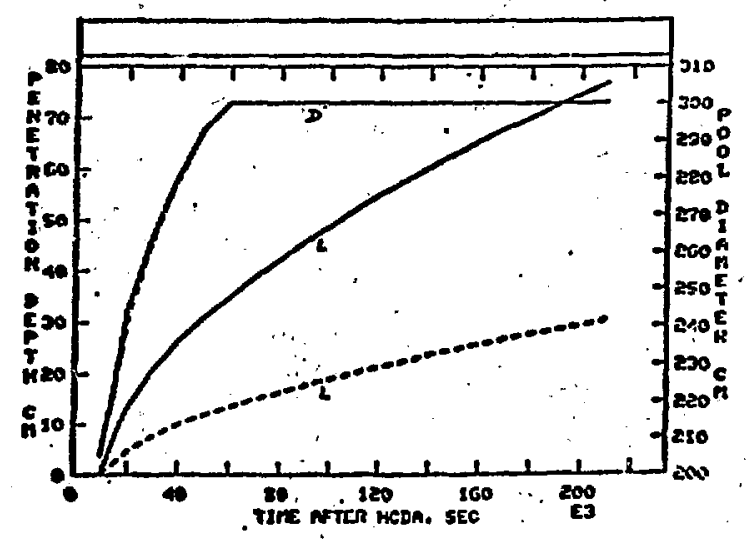

F19. 9. Pool Dlameter and Penetration vs Time for a Sacrificlal Bed of Magnesia by. two Versions of GROWS (dashed lines. refer' to case where effects of mas's transfer were Ignored; solid lines refer to case where mass transfer effect was included).

magnesia ar plotted [29]. The dashed curves corr uspond to the case where the effects "of mass transfer were ignored and the solid curves include an approximate treatment of the effect based on a heat transfer-mass transfer analogy. The results show that the extent of downward penetration depends strongly on the model. used to take account of the mass transfer offect. However, the results, based on the total core inventory for FFTE, also show that the pool diameter increases from an initial value of $2 \mathrm{~m}$ to 3 is in about $16 \mathrm{hr}$ while the downward penetration is less than $400^{\prime} \mathrm{mm}$. These penetration rates are typical of the gind of performance which might be expected from the sacrificial barrier concept.

One way tó avoid uncertainties about the mass transfer effect is to employ a sacrificial material of density greater than that of the fuel. Such materials inc:lude urania and thoria. The current design of the core retention system in the SNR-300 does call for UO, bricks as a iner material. However, considerable cost is involved in using large quanti-. ties of these materials. Also, there is no available capacity for fabricating large quantities of $\mathrm{UO}_{2}$ or $\mathrm{ThO}_{2}$ into bricks. It would appear that available materials such as magnesia might be equally suitable and far more economical.

\section{Stable Barrier Concept}

In this concept, a refractory material is used which is capable of containing the core debris even without conling. To do this, the refractory material must not melt or be attacked by core debris up to temperatures equal to the boiling point of fuel. Both graphite (and several carbides) and tungsten have sufficiently high melting temperatures: Tungsten or other refractory metal's are not promising materials because they would be attacked rapidly by the moiten steel content of the core debris. Graphite is a promising material for this application even though there are chemical reactions between graphite and core debris. Refractory carbides such as tantalum carbide might have better chemical resistance" than graphite; however, the cost of such materials would be excessive.

Graphite can form chemical compounds with sodium. However, tests have indicated that high density graphite is not attacked by liquid sodium, including. boiling sodium, for significant periods: of time [25].

Molten steel dissolves considerable guantities of carbon to form a mixture with a eutectic melting temperature about $1150^{\circ} \mathrm{C}$. The $(\mathrm{U}, \mathrm{Pu})^{\circ} \mathrm{O}_{2}$ of the fuel will react to form mixtures of $(\mathrm{U}, \mathrm{Pu}) \mathrm{C}$ and (J,Pu) $\mathrm{C}_{2}$. These carbj.des also tend to form double carbides with the steel compounds such as (FeU) $C_{2}$. The principal problem with these interactions is the conversion of th? oxide content of the fuel into carbon monoxide gas. A recent study of the interactions of graphite with $\mathrm{UO}_{2}$ and steel indicated that rapid reaction began for the graphite- $\mathrm{UO}_{2}$ system at about $2400^{\circ} \mathrm{C}$ where a molten carbide' is generated [30]. In the presence of steel, the terperature for the onset of rapid reaction was reduced to about $2000^{\circ} \mathrm{C}$. At these temperatures, substantial conversion of the oxide fuel to carbides and the release of $\mathrm{CO}$ occurred in less than 15 min. The magnitude of the gas release was a principal 
reason for not using graphite as the liner anterlal in the SNR-300 resctor (see Fig. 2). The current design employs $\mathrm{UO}_{2}$ brlcks as the 1 iner material [2]. although $c 0$ generation 13 a disadvantage of the graphite barrier coneept. there are ignificant advantages. once tha reactions are completed, the heavy ata 1 carbides ;each a chenical equilibIu with the underlying graphite and a -table containment situation should be achieved. Also, graphite is relatively Inexpensive. The high thermal conductivity of graphite would tend to prevent localized regions of high heat flux and facilitate design of heat removal systems.

\section{Catch Thay Concept}

In this concept, a system of trays is arranged so as tó intercept the downward motion of the core debris: The trays may be Imuersed in sodium initially or reliance must be placed on the expectation tirat adequate odium will be available Irom the primary system at the same time as the core debris hagins entering the cavity. The catch tray concent is especially promising for pool-type reactors where space is more available for a tray system that is subnerged in primary system rodium within the reactor vessel. A tray system, designed for collection of a fraction of the total fuel inventory, for the super-Phenix reactor is indicated in PLg. 10.

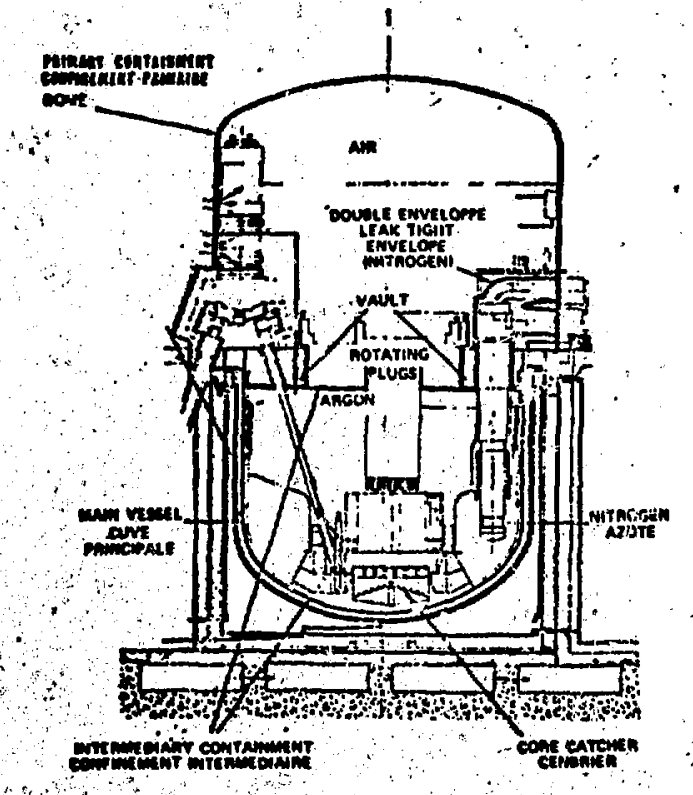

Hig. 20. Crosenection of super-Phentx Resctor.

The downard elow of molteu core webris: triough sodium is expected to reoult in quenching and fragmentation into particuiate form, as noted previously:
Core debris entering trays would be in particulate form. However, the performance of a tray system does not necessarily depend on the completeness of particulate formation. Core debris in the form of molten material or large solid pieces could also be intercepted by a tray system. Since the trays are cooled by sodium rrom the underside as well as from above, there is no need to depend upon infiltration of the debris bed bu sodium.

Heat removal from the tray system is facilitated by the arrangement: of the trays to achieve vigorous natural convection heat transfer to the sodium. Heat removal from the sodium pool at higher elevations is needed to maintain the convection process and afford an ultimate heat sink:

\section{INHEKENT RETENTION CAPABILITY}

The CnBR Project has contenojed that a covled core-retention system in the reactor cavity is not necessary because of the inherent retention capability of the concrete base mat below the reactor cavity. This capability is one of several features referred to as "thira level thermal margins". The third livel refers to the third level of reactor safety [31] and the thermal margins refer to the fact that the processes which would function to mitigate the raciological conseguences of HCDAs occur spontaneously. One of the s:avected processes is the entombment $\because \because$ the nonvolatile core debris withir: ise concrete of the base mat. Because o: the CRBR approach, the interactions oi core debris with concrete have come uncler intensive. study aince about 1975. Core debris interactions with concrete are reviewed in the following paragraphs.

The general features of the behavior of concrete at temperatures up to the order of $1000^{\circ} \mathrm{C}$ have been established by experiments concerned with. the fire resistance of structures. Detailed ipecification of the behavior of concrete under transient thermal conditions are complicated by the large number of types and compositions of concrete. While the general features of dehydration and decarboxylation of concretes are known [32]. means to preciict detailed behavior for specific compositions were not available unti.l very recently. Also, information on the behavior of concretes in contact with core desris is in a preliminary stage of development.

\section{Transient Herting and Dehydration of concrete}

Iransient heat transfer in concrete Is a key aspect of core debris interaction processes. This is especially true because-of concrete decomposition which leads to dehydration and gas re- 
Iease. The release of water vapor and other gases, which depends on the penetration of heat into the concrete, may greatly affect the composition of the core debris as well as the heat transfer processes within the core debris. The water content of concrete can be considered in two parts. One part, called free water or evaporable water, is contained within capillaries and is largely released by heating to temperatures slightly above $100^{\circ} \mathrm{C}$. The other part of the water content is more strongly bound and much of it is chemically bound within the cement phase. Bound water is released over a rather wide range from just above $100^{\circ} \mathrm{C}$ to about $900^{\circ} \mathrm{C}$. The peak release rate generally occurs around $500^{\circ} \mathrm{C}$. so that to a first approximation, bound water can be considered to be released at $\sim 500^{\circ} \mathrm{C}$.

Iimestone concrete contains quantities of calcite, $\mathrm{CaCO}_{3}$, and dolomite, $\mathrm{KgCa}\left(\mathrm{CO}_{3}\right)_{2}$, whinh decompose to calcia, CaO, and magnesia, $\mathrm{MgO}$, and release $\mathrm{CO}_{2}$ gas. The decomposition of the carbonates occurs in the range 600 to $1000^{\circ} \mathrm{C}$.

Dolorate decorposition to $\mathrm{MgO}$ and $\mathrm{CaCO}_{3}$ occurs in a temperature range near $700^{\circ} \mathrm{C}$ while the calcite decomposes around $900^{\circ} \mathrm{C}$ [33].

Transient heating experiments with concrete have been performed in severa? ways: (1) Constant rate heating at $23^{\circ} \mathrm{C} /$ min [33]. (2). Exposure to a constant temperature of $2900^{\circ} \mathrm{C}$ at one plane boundary [34]. and (3) Exposure to a constant heat flux ranging from 300 to $3000 \mathrm{~kW} / \mathrm{m}^{2}$ at one plane boundary [35]. There was no spalling or fragmentation observed in any of these experiments. However, sample dimensions were less. than abcut $200 \mathrm{~mm}$ and none were strongly constrained nor did they have steel reinforcing. surface apaliing has been observed in fire tests with large sections [36]. In general, the spalling is confined to the material within a few centimeters of the heated surface.

The thermal conductivity of many gravel concretes, by a standard (steadystate] method [37], can be represented approximately $[32,33]$ :

$$
k=1.95\left(1-0.000563 \mathrm{~T},{ }^{\circ} \mathrm{C}\right) . \mathrm{W} / \mathrm{mK}
$$

which is the dashed line in Fig. 11. Concretes prepared from low conductivity aggregates can have conductivity values of the order of $0.5 \mathrm{~J} / \mathrm{mk}$.

Transient heating experiments with concretes have shown that for onedimensional experiments, the results can be represented by a similarity variable which combines the efferts of distance and heating time $[34,38]$. A similarity plot for a Iimestone concrete is shown in. Fig. 12. It is apparent from Fig. I2 that the transient heating results could not be accounted for on the basis of a

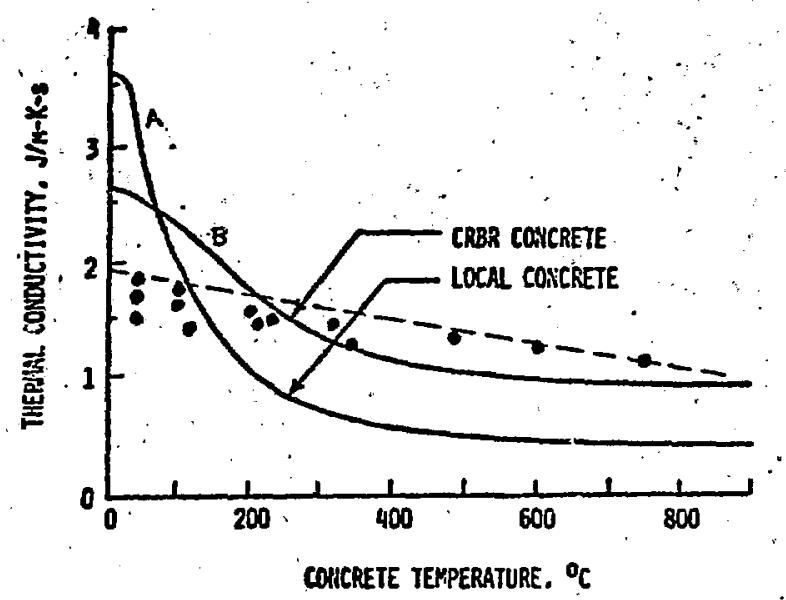

fig. 11. Thermal Conductivity of Gravel Concretes from Several Sources, (Points are from [ $\leqslant 2$ ]; solid Lines are from [34] and [42]; Dashed Line is from [33].

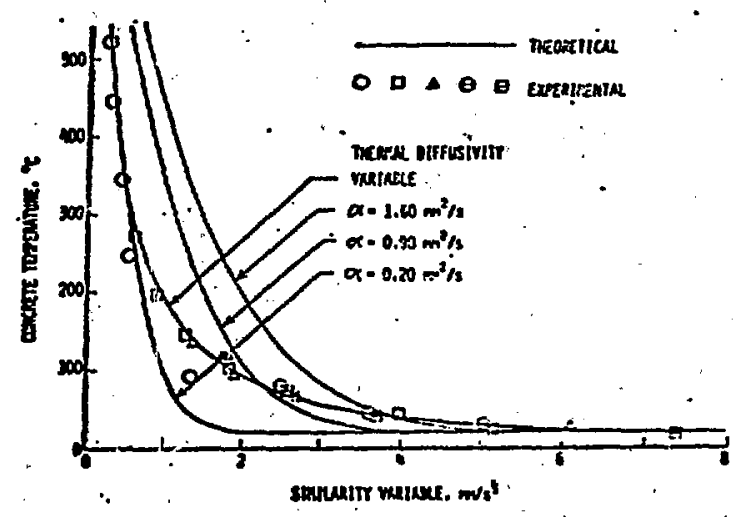

Fig. 12. Diffusion of Heat in Concrete at jlevated Temperature from [34].

single value of thermal diffusivity. independent of temperature: Instead, an empirical. equation for an effective thermal diffusivity, " $\alpha$ ff, which varied from a constant high value at $25^{\circ} \mathrm{C}$, $a_{0}$. to a constant low value at temperatures above $801^{\circ} \mathrm{C}, \alpha_{\mathrm{g}}$, was. used:

$$
\begin{aligned}
\frac{\alpha_{e f E}}{\alpha_{0}} & =1-\frac{1-\alpha_{0} / \alpha_{0}}{2}\{1+\operatorname{erf} \\
& {\left.\left[4\left(\frac{1-T_{0}}{T_{0}-T_{0}}\right)^{n}-2\right]\right\} }
\end{aligned}
$$

The results for two limestone concretes are shown in Fig. 11 . Curve $A$ coríesponds to the silica-containing limetone concrete of Fig. 12 while curve $B$ refexs to a limestone concrete containing Elyash which corresponds closely to 
the nfxture specified for CRBR.

The high values of conductivity at Low temperature (Fig. 1.1) obtained by

the transient method may have resulted

from the leat transport effect of water or water vapor moving away from the

heated surfaces, while the low values at high temperatures could have been caused by the motion of steam toward the heated surface, In the experiments represented by Curve $A$, ilquid water was rejected at the cold end of the sample: This did not. occur for the concrete represented by Curve B. The low conductivity at high temperature could have been caused partly by the porosity created by the loss of $\mathrm{CO}_{2}$ gas.

Equation (1) has been used in conjunction with an approximate analytical treatment of transient conduction which takes, account of the heat absorption by evaporable water release at $100^{\circ} \mathrm{C}$, bound water release at $500^{\circ} \mathrm{C}$ and $\mathrm{CO}_{2}$ release at $700^{\circ} \mathrm{C}[34]$. The model is capable of predicting the extent of gas release on the assumption that the three types of gases are released, each at a single value of temperature. The temperature values and the magnitude of the heat effects can he varied to obtain parametric results. A model of gas release has been proposed that is based on first order kinetic release of the three species based on an interpretation of thermo-gravimet $x$ ic analyses of small concrete specimens [39]. Concrete heat transfer and gas release models in the form of finite element codes are in various stages of development. other concrete properties, including specific heat density, and heats of decomposition can be evaluated from an . analysis of the composition using the methods described by Harmathy [32]. Based on the methods currentiy in hand or under development, it would appear that the transient heat transfer and gas release for concretes can be calculated "within a "reasonable uncertainty providéd small-scale experimental results are availabie for the specific compositions of interest. Changes in behavior which migtit be caused by cracking, spallIng, or by the presence of reinforcing Gars in large sections cannot be predicted adequately by available methods at this tine.

\section{Concrete Interactions with sodium}

The principal initial interaction "of' concrete with core debris is expected to be the reaction with sodium. Preliminary results are available from experiments in which hot sodium was poured on concrete. samples $[40,41]$. Results have been obtained for interactions at horizontal aurfaces and at vertical surfaces. Penetration rates were about $12 \mathrm{~mm} / \mathrm{hr}$ for busaltic concrete and about $25 \mathrm{~km} / \mathrm{hr}$ for high-density magnetite concrete. A rate of about ' $12 \cdot \mathrm{mm} / \mathrm{hr}$ was found for a Tennessee limestone concrete for five hours of exposire to sodiun very close to the boiling temperature [33].

The sequence of chemical reactions Involved in the attack of sodium on concrete is complex and pocrly understood. Experimental results combined with thermodynamic analysis have indicated which chemical reactions are likely to be most impol'tant: The water evolving from the concrete reacts with sodium in two ways:

$$
\begin{aligned}
& 2 \mathrm{Na}+\mathrm{H}_{2} \mathrm{O}+\mathrm{Na}_{2} \mathrm{O}+\mathrm{H}_{2}, \\
& \mathrm{Na}+\mathrm{H}_{2} \mathrm{O}+\mathrm{NaOH}+\mathrm{H} / 2 \mathrm{H}_{2} .
\end{aligned}
$$

Reaction (2) is expected to predominate in the fresence of excess sodium. These reactions are major sources of heat during the interaction.: The $\mathrm{CO}_{2}$ evolving frbm the concrete can react with sodium oxide or with sodium as follows:

$$
\begin{aligned}
& \mathrm{Na}_{2} \mathrm{O}+\mathrm{CO}_{2}+\mathrm{Na}_{2} \mathrm{CO}_{3} \\
& 4 \mathrm{Na}+\mathrm{CO}_{2}+2 \mathrm{Na}_{2} \mathrm{O}+\mathrm{C}, \\
& 4 \mathrm{Na}+3 \mathrm{CO}_{2}+2 \mathrm{Na}_{2} \mathrm{CO}_{3}+\mathrm{C} .
\end{aligned}
$$

Reaction (4) is favored when sodium oxide is available in the melt. Reactions (5) and (6) are thermodynamically favored over similar reactions which would evolve co. Elemental carbon has been found in the reactant mixtures in experiments [34]. These results indicate that little or no $\mathrm{CO}_{2}$ or $\mathrm{CO}$ may be evolved so long as an excess of sodium is present above the concrete surface.

The most reactive of the concrete constituents is expected to be silica, $\mathrm{SiO}_{2}$, or silica containing minerals such as basalt, which react to form a very stable series 'of silicates, including sodium siliçate:

$$
\mathrm{Na}_{2} \mathrm{O}+\mathrm{SiO}_{2}+\mathrm{Na}_{2} \mathrm{SiO}_{3}
$$

Concrete containing magnetite, $\mathrm{Fe}_{3} \mathrm{O}_{4}$, or ferzite $\mathrm{Fe}_{2} \mathrm{O}_{3}$ would be expected to react with sodium to generate Feo and possibly Fe. The principal reaction is:

$$
\mathrm{Fe}_{3} \mathrm{O}_{4}+2 \mathrm{Na}+\mathrm{Na}_{2} \mathrm{O}+3 \mathrm{FeO} .
$$

The $r$ cher concrete constituents, CaO, Mgo, $\mathrm{An}_{2} \mathrm{O}_{3}$, etc. . would be expecterd to be soluble to some degree in the molten mixture of sodium oxides; carbonates, and silicates, along with ferrous oxide.

As long as sodium is present, the temperature is limited to about the boiling point of sodium $\left(883^{\circ} \mathrm{C}\right)$. At this temperature, the calcia and magnesia content of the dried concrete surface does. not melt and should not react with sodium. Because of this, it is expected that sódium attack on. concrete hould stop' at some depth depending upon the quantity of . 
the sodium available to form the sodium oxide/carbonate mixture. Dissolution of the concrete constituents would stop once the mixture was saturated in calcia and magnesia. This solubility limit is consistent with available observations of a limited penetration; however; more experimental work is required before a satisfactory understinding of the process is available.

\section{Concrete Interactions with Molten steel}

The steel content of the core debris should be in the form of metallic particulate which would remain intact as long as an excess of sodium is present.

However, once the metallic sodium is largely boiled off, the temperature in the oxile layer would be free to increase and steel melting would occur at $21400^{\circ} \mathrm{C}$. The molten steel is more dense than the molten oxide-carbonate mixture and would tend to form a layer separating tive concrete from the molten oxide/carbonate layer.

The gerieral nature of the interaction of molten steel with concrete has been established by induction heating of the steel and by pours of thermitegenerated steel into concrete crucibles. $[34 ; 35\}$. The continuous releas'z of gases from the concrete causes a vigorous Initial bubbling of the melt layer that tapers off with time as the gas release rate decreases. Gas analysis has shown that the evolving water vapor and $\mathrm{CO}_{2}$ are efficifntly reduced to $\mathrm{H}_{2}$ and $\mathrm{CO}$, respectively. When the gases are not shielded from air, a steady flame is pioduced. The oxysen lost from the gases oxidizes the steel to an $\mathrm{Fe}_{3} \mathrm{O}_{4}$ type of oxide mixture in which the nickel and the chromium contents of the stainless steel take the place of some of the iron. The oxide mixture in the experiments formed a growing overlying layer which appeared to be a single phase. This is shown by the experimental cross-section in Fig. 13. Under the reactor accident conditions, the upper layer would include the residual oxide mixture composed of sodium oxide, carbonate, and silicates. Whether this layer would be a single phase or several phases is not known.

The continuous generation of molten axides of steel causes a continuous dissolution of the dried concrete constituests at a steady pel. -tration rate from $70 \mathrm{mn} / \mathrm{hr}$ (Ref. 34 ) to as high as 1 $\mathrm{m} / \mathrm{hr}$. With basaltic concretes, an incipient melting region was observed between the concrete and the steel layer [35]. with a limestone concrete having very low contents of silica and magnetite (CRBRtype conorete), the region between the intact concrete and the melt appeared refiactory and somewhat powdery $[42\}$. In the latter case, concrete penetration was

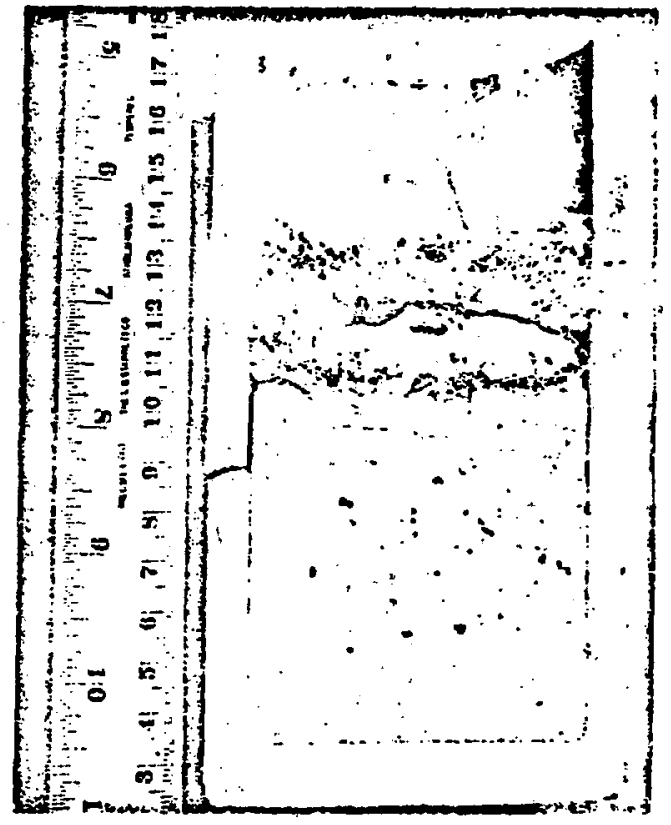

Fig. 13. Cross-section from Molten SteelConcrete Interaction Experiment [34].

probably by dissolution and not by melting. Recent tests have shown that the melting point of the dried concrete is much greater than the melt temperature in the experiments with CRBR-type concrete [42].

\section{Concrete Interactions with Molten Fuee}

As noted previonsly, fuel content of the core debris which would interact with the concrete of the cavity would be expected to be in particulate form. The dense particulate would tend to settle into the growing layer of molten oxides and carbonates. The (U,Pu) $\mathrm{O}_{2}$ fuel would be likely to dissolve in the layer. although no actual values of the solubilities are available so that it is uncertain just how long the dissolution process would take. In this situation, there would be no direct attack of pure molten fuel on concrete.

Some small-scale tests of the attack of molten $\mathrm{UO}_{2}$ on concrete were performed to establish the general nature of the interaction process [34]. Electrically heated molten $\mathrm{UO}_{2}$ was found to penetrate concrete at about the same rates as moltei? steel. The evolution of gas resulted in ejection of freezing druplets of a glassy material composed of solutions of $\mathrm{UO}_{2}$ and the oxides of concrete. The solidified pools appeared to be an opaque glass having a density of the order of 3000 to $4000 \mathrm{~kg} / \mathrm{m}^{3}$. 
Tuhetent Retention scenario:

The downward fiow of molten core debris from the failed reactor vessel is cxoected to result in an interaction with sodfun producing a particulate bed of fuel and steel at the bottom of the sodium pool In the reactor cavity. The bed should spread over most of the available crosssection of the cavity. If it is assumed that the steel liner has failed, then the reaction of sodium with concrete will begin immediately. The heating of the concrete causes the release of water vapor and $\mathrm{CO}_{2}$ gas. The water vapor will generate sodium monoxide according to Eq.. (2) and the $\mathrm{CO}_{2}$ will convert a portion of the sodiun monoxide to sodium carbonate according to Eq. (4). These reactions should lead to the buildup of a growing oxide/carbonate layer between the sodium and the concrete. Limited penetration of the concrete will occur as the oxides of concrete dissolve in the oxide layer up to the solubility limit.

During, the time of buildip of the oxide layer, the dense $\mathrm{vO}_{2}$ and stainiess steel particulate would tend to settle into the layer where some or all of the $\mathrm{VO}_{2}$, including the fission product oxides, would dissolve in the oxide melt. Most of the decay heat would be transferred upward to the boiling sodium which would graduaily be ariven out of the cavity as vapor. The distillation of sodium from the reactor cavity to the containment building is estimated to reguire about 10 days under the conditions of the CRBR carity [4].

Following completion of sodium removal from the cavity $:$ the decay heat generated within the oxide layer could no longer be removed at or near the temperature of boiling sodiun. Consequently, the temperature would rise until sufficient heat loss could occur. When the temperatures reached slightly above the melting temperature of steel, $21400^{\circ} \mathrm{C}$, a large heat sink would become available, corresponding to the heat of fusion of the reactor and guard vessels and other ateel components within the cavity. The smallscale molten steel-concrete experiments have shown that the continued release of water vapor and $\mathrm{CO}_{2}$ results in steel oxidation to FeO and $\mathrm{Fe}_{3} \mathrm{O}_{4}$. These oxides would mix with the existing oxide pool." The continued growth of the oxide pool and the increased pool temperature would lead to a continuing penetration of the concrete base mat.

Concrete penetration would stop. pormanentiy when the heat removal capability in the upward and dowiward directlons becones equal to the decay heating rate at a pool temperature less than the wating point of the dried concrete. Upwird heat removal in expected to occur by therini radiation from the upper eurface of the pool while downard heat renoval
Is by conduction through the remaining concrete, into the earth below the concrete. Both processes of heat removal are improved by radial growth of the pool which increases the heat transfer area. Detailed evaluation of the ultimate penetration capability depends mainly on achieving an improved understanding of the relative processes of pool growth in the sideward and downward directions. The high ratios of sideward to downward heat flux observed in water pool experiments under nonboiling and under boiling conditions (see Fig. 7) offer considerable promise that large radial growth wili occur so that downward penetration will. be quite Ij.mited.

The potential for concrete spalling is a significant uncertainty in penetration analysis. Available information indicates that spalling is limited to thin layers close to the heated surface. Also, spalled material would be melted into the pool and thereby absorb heat of fusion and contribute to the dilution of the heat source to the same degree as concrete which had not spalied. Spontaneous breakup of thick sections, which would have major effects on penetration predictions, appears to be very unlikely.

\section{CONCLUDING REMARKS}

Post-HCDA, core-debris behavior is considered in three locations: (1) within the reactor vessel, (2) within the cavity below the reactor vessel, and (3) within the concrete below the reactor cavity. In-vessel behavior is dominated by considerations of the frajmentation of molten fuel and steel on quenching in an excess of sodiun to form particulate debris beds. In-vessel coolability depends primarily on the availability of sufficient horizontal surface area so that the particulate bed depth is not excessive and on the requirement that removal of small quantities of heat from the reactor vessel continues.

Core debris behavior in the reactor cavity can be controlled in several different ways. An uncooled cavity liner could maintain its integrity for many days wile the decay heat is absorbed by sodium boiloff from the cavity. An engineered cooling system in the cavity could result in the permanent coolability of core debris in the cavity. such a system could be based on one of four general concepts: including (1) the cooled crucible concept, (2) the sacrificial barrier concept, (3) the gtable barrier concept, and (4) the catch tray concept. Each concept has a different set of advantages and disadvantages. However, each would appear to be. a viable approach to core retention.

Core debris behavior within the concrete below the reactor cavity is a key oleiment in the "inherent retention 
concept" "Evaluation of the concept depezds upon development of an improved understariding of several phenonena. especially pool radial growth and concrete spaliing. Based on current understanding, there is an expectation that core debris penetration into a typical reactor base mat would stop short of total penetration [4].

Recent studies of core debris behavlor relative to all three locations have led to a great improvement in the understanding of the appropriate pheromena. It now appears that a range of options are available to the reactor designers and the safety evaluators concerned with the recention and coolability of the debris that could be generated in the exiremely unlikely event of a hypothetical core-disruptive accident in an IMFBR test reactor or power plant.

\section{REFERENCES}

[1] Supplement No. 2 to the safety Evaluation of the Fast Flux Test Facility, Project No. 448, U.S. Nuclear Regulatory Commission, Division of Reactor Licensing, Washington, D. C. (March 7, 1975).

[2] E. Kugler and $S$. Wiesner, "Licensing Aspects in the Verification of the SNR 300 Design Concept Against Hypothetical Accidents," Proc. Int. Heeting on Fast Reactor safety and Related Physics, Chicago (Ostober. 1976).

[3] CRBR Ex-Vessel Core Catcher Concept Evaluation Report, WARD-D-0103 (October 1975).

[4] Third Level Thermal Margins in the Clinch River Breeder Reactor Plant (Apri1 1976).

I5) T. R. Johnson, J. R. Pavlik, and I. Baker, Jr.. "Postaccident Heat Removal: Large-Scale Molten-FuelSodium Interaction Fxperiments." ANL-75-12 (February 1975).

[6] L. Eaker, Jr. and J. D. Bingle, - Analysis of Core-debris Retention in Reactor Vessel," in Reactor Development Program Progress Report, ANL-RDP-40, p. 7.59 (May 1975).

[7] I. Baker, Jr. et al.." "Postaccident Heat Removal," ANL7Rñs 74-12 (July 1974).

[8] J. D. Gabor et al.." "studies and Bxperiments on heat Removal from Fue1 Debris in sodium," Proc. Fast Reactor Safety Meeting, CONF-740401P2. P. 823 (April 1974).

[9] H. C, Hardee and R. H. Nilson, Matural Convection in Porous Media with Heat Generation," SAND 76-0433 (Decernber 1976).

[10] V. K. Dhir and I. Catton, "Prediction of Dryout Heat Fluxes in Beds of Volunetrically lleated Particles," Proc. Int. Meeting on Fast Reactor
Safety and Related Physics, Chicago (October 1976).

[1i] G. R. Armstrong, "Postaccideat Heat Removal Assessment for the FFTF," HEDL-TME 75-60 (November 1974).

[12] E. L. Gluekler, R. M. Clever, and E. T. Rumble, "Investigations of the structural Integrity of a Reactor Vessel for a Postulated Core Meltdown Accident," Paper G10-E, This Conference.

[13] E. S. Sowa et al.. "Studies of the Formation and cooling of Particulate Fuel Debris Beds in Sodium," Proc. Int. Meeting on Fast Reactor Safety and Related Physics, Chicago (October 1976).

[14] M. M. Chen, "Erosion of a Low Melting solid by a Hot Fluid Jet oi Normal Incidence," submitted to AIChE for 1977 National Heat Transfer Conference.

[15] E. L. Gluekler, "Ex-Vessel core Retention Concept for Early sized LHFBRs," GEAP-14121 (August 1976).

[16] F. A. Kulacki and R. J. Goldstein, J. FJuid Mech. 55, Part 2, 271 (1972).

[17] M. Jahn and H. H. Reineke, "Free Convection Heat Transfer with Intexnal Heat Sources, Calculations, and Measurements," Paper NC2.8 (and discussion), 5th Int. Heat Transfer Conf., Tokyo (September 1974).

[18] R. S. Peckover and L. H. Hutchirson, phys. Fluids 17, 1369 (1974).

[19] I. Catton and A. J. Suo-Anttila, "Heat Transfer from a Volumetrically Heated Horizontal Fluid Layer," Paper NC2.7, 5th Int. Heat Transfer Conf.. Tokyo (September 1974).

[20] I. Baker, Jr., R. E. Faw, and F. A. Kulacti, Nucl. Sci. Eng. 61, 222 (1976).

[21] I. Baker, Ir. et al. "Heat Removal from Molten Fuel pools," Proc. Int. Heeting on Fast Reactor safety and Relaced Physics, Chicago (Ocțober 1976).

[22] F. Mayinger, M. Jahn, H. H. Reineke, and $U$. Steinbrenner, "Examination of the Thermohydraulic Processes and Heat Transfer in a Core Melt," BMFT R8 $48 / 1$.

[23] J. D. Gabor, L. Baker, Jr., J. C. Cassulo, and G. A. Mansoori, "Heat Transfér from Heat-Generating BoilIng Pools," 16th Nat. Heat Transfer Conf., st. Louis (August 1976) Paper AIChE-7.

[24] S. G. Bankoff and A. C. H. tuk, "sinulation of Boiling Pools with Internal Heat sources by Gas Injection," the Second Annual postAccident Heat. Removal (PAJIR) "Information Exchange," SAND 76-9008 (November 1975), p. 169.

[25] J. K. Fink et aí." "Interactions of Certain Refractory Materials with sodium," ANL-75-74 (May, 1976). 
[26] S. A. Meacnam, "Sodium Capability of Refractory Materials Contained for CRBR Paraliel Design Ex-vessel Core Retainers," WARD-D-009? (April 2975).

[27] D. G. Swanson et al., "Annual Progress Report, Ex-vessel core Catcher meterials Interactions," ATR-77 7608)-2 (October 1976).

[28] R. Farhadieh, L. Baker, Jr., and R. B. Faw, "Studies of Pool Growth with simulant Materials," the second Annual Post-Accident Heat Removal (PAHR) "Information Exchange," SAND 76-9008 (November 1975), p. 271.

[29] R. Kumar, "Modeling of Fool Growth," the second Annual post-Accident Heat Removal (PAHR) "Information Exchange." SAHD 76-9008 (November 1975), p. 279.

[30] M. Peehs, G. Hofer, H. J. Friedrich, and $H$. J. Heuvel, "Experimential Investigations of the compatibility of' a SNR-Type Corium with Graphite," proc. Int. Meeting on Fast Reactor safety and Related Physics, Chicago (October 1976).

[31] Volune 10, Safety of the Liquid Metal Fast Breeder Reactor Program Plan. HASH-1110 (August 1968).

[32]. T. 2. Harmathy, Journal of lhaterials, JMLSA, 5, No. 1 (March 1970),

(33) S. A. Meacham, "The Interactions of Tennessee Iimestone Aggregate Concrete with Iiquid sodium," WARD-Do141 (December 1976).

[31] I. Baker, Jr. et al., "Interactions of LMFBR Core Debris with concrete," proc. Int. Meeting on Fast Reactor safety and Related Physics, Chicago (October 2976).

(35) J. F. Muir, D. A. Powers, and D. A. Dahlgren, "Studies on Molten FuelConcrete Interactions," Proc. Int. Heeting on Fast Reactor Safety and Related:Physics, Chicago lOctober 1976).

[36] T. T. Lie, "Fire and Buildings," Applied Science Pub. Ltd., London (1972).

[37] "Standard Method of Test for Thermal conductivity of unfired Monolithic Refractories," ASTM Procedure C 41772.

[38] J. Muir, Sandia, private communication (1977).

(39] D. Powers, Sandia, private communication (1977).

[40] J. A. Hassberger, R. K. Hilliard, and L. D. Muhlestein, "Sodium-Concrete." Reaction Tests," HEDL-TME 74-36 (June 1974).

[11] R. K. Hilliard and w. D. Boehmer, concrete Protection from Sodium Spilis by Intentionaliy Defected Iners--Small-scale Tests $S 9$ and 810," HEDL-TME 75-75 (July 1975).

[42] F. B. Cheung, ANL, private communioation (1977). 